\title{
FROM THE EDITORIAL BOARD
}

\section{THE MOTIF OF APPLE IN DIFFERENT CULTURES AND ITS USAGE IN ANATOLIAN FOLK SONGS ${ }^{1}$}

\author{
Ahmet Emre Dăğtaşoğlu
}

\begin{abstract}
Every culture employs some motifs that are peculiar to its semantic world. These motifs have a vital importance for understanding some issues within the cultures in which they function as their codes. Some of these motifs that emerge in different cultures and eras have, surprisingly, very common meanings despite their varieties in time and place. One of these motifs frequently encountered in different times and cultures is 'apple'. In this study, the motif of apple is discussed by pointing out its meanings in different cultures, and then the Abrahamic religions are examined in this context. Finally, this motif is analyzed in the context of Anatolian folk songs. In this way, the meanings that cannot be understood in a folk song text by means of ordinary reading are clarified, and the relations of this motif in Anatolian folk songs and other cultures are introduced.
\end{abstract}

Keywords: Abrahamic religions, Anatolian folk songs, apple, cultural motifs, mythology

\section{INTRODUCTION}

Every culture has a system of symbols that occurs in the context of the semantic horizons of these cultures. Some of these symbols are rarely used as motifs both in folktales and artworks. One of them, which has a widespread usage in a great deal of cultures, is the motif of apple. In this paper, the common meanings of apple in different cultures are pointed out by discussing its various usages. Then, the motif of apple is studied in the context of Anatolian folk songs by referring to the texts of these songs.

For this purpose, the study includes examples from Europe, Middle East, and some parts of Asia since they encircle Anatolia both geographically and culturally. In addition to that, factors like wars, migrations, and trade relations provide continuous connection and cultural transitivity between these regions (Hentsch 2008: 15, 66-67). Besides, the consideration of apple in Abrahamic religions is put on the agenda by virtue of their dominant influence on the cultural structure of Anatolia. A wide time span is also taken into consideration 
in this study for the reason that cultural values not only have permanence both in time and geography (place) but they also emerge in different periods of time with meanings close to their old usages, i.e. in similar forms. Thus, common points in the considerations of apple in different cultures are determined and a general framework is suggested about the reception of apple by these cultures. Then, the usage of the motif of apple in Anatolian folk songs is discussed through a hermeneutical reading, and, depending on this, the similarities between Anatolian folk songs and artifacts of other cultures in the usage of apple as a motif are stressed. As a result, it is possible to clearly see the common usage of apple in different cultures and to figure out some obscure issues about the texts of Anatolian folk songs on the basis of this historical background.

\section{THE USAGE OF APPLE AS A MOTIF IN DIFFERENT CULTURES}

An overview of the history of culture shows that the motif of apple has varied meanings and functions, such as abundance, fertility, peace, wealth, and proliferation; for this reason it is considered as a valuable gift. For instance, according to the Chinese it is "an acceptable gift, especially since the apple (ping) can stand as a symbol for 'peace' (ping)" (Eberhard 1986: 16). Besides, "in China wild apple blossom denotes female beauty" (Hall 1996: 142). Apart from being a symbol of beauty, it also has a therapeutic property in many cultures, since it is thought to be a magical fruit which can cure all the diseases. For example, the Celts believe that apple is an excellent medicine and it can cure most diseases (Macbain 1885: 72). By the way, "some Irish legends speak of a food that, when eaten by the gods, kept them young and hale" (Monaghan 2004: 257). There are some suggestions about this food, but the strongest one among them says that this food is apple, and it comes from the other world (ibid.). Again, according to a belief in Irish mythology, Cormac mac Airt "had a silver branch that bore three golden apples and that made music to soothe the sick" (Coleman 2007: 240). In the Norse myths, however, there are apples of Braghi which can cure all sorts of illnesses and provide immortality to gods (Coleman 2007: 164; see also Jordan 2004 [1993]: 53). As well as this myth, in Norway there is also a myth about Gna, the wife of Rerir, who gave birth to a boy after eating an apple (Coleman 2007: 875, 419, 1086).

The therapeutic property of apple is prevalent not only in Western cultures, but it is a frequently encountered motif in Eastern cultures as well. In The Arabian Nights there is an apple which can cure illnesses. In the tale "Prince Ahmad and the Fairy Peri-Banu", the scent of a magical apple bought from Samarkand by Prince Ahmad cures patients, and he cures Princess Nur 
Al-Nihar by the agency of this magical apple (Book 1887: 434, 439). It is well known that the Turks also believe in the therapeutic property of apple just like many other nations. For example, "apple is the symbol of abundance, fertility, proliferation, treatment, and communication in Anatolia" (Altun 2008: 263; see also Sever 2004: 97; Keskin 2001: 43; Tozlu 2011: 359). In a number of folktales, the treatment of patients, especially infertile women, is possible by the agency of apple (Aça 2005: 13). Moreover, it is not only in Anatolia that apple is considered in this manner; it has similar meanings also in central Asia. For instance, in the Epic of Manas, Aydar Khan's daughter cannot give birth to children and, according to her husband, one of the important reasons is her carelessness about wallowing in the apple garden (Radloff 1995: 10-25). The following is a passage from Jean-Paul Roux:

In the epic of Manas, Jakip sends his wife to see an apple tree in the environs of a holy well for the purpose of remediating her infertility. Infertile Kazak women roll on the ground at the bottom of an apple tree to become pregnant. Turks in Turkey expect the visit of an old man while they are bivouacking at the bottom of a tree. (Roux 2002: 181)

Plenty of different examples can be found in this context but my aim is not to examine the motif of apple in all its aspects. Thus, the overview about the motif of apple given above seems to be sufficient for my purpose as this study specifically focuses on a more common meaning of this motif in different cultures by disregarding its other meanings. Although this specific common meaning of apple is related to others, it has a more extensive and significant horizon than the other ones. According to this horizon of meaning, apple indicates both emotional and sexual relations between men and women. In connection with this, it functions as a communication tool. We can trace clear evidence of this usage of apple from ancient Greece to the modern era. Almost all of the apple motifs in ancient Greece indicate, either directly or indirectly, some aspects of relations between men and women. Depending on its usage, apple might mean communication between men and women, a proposal to the lover, or marriage.

The first example of this motif in this context is the golden apples in the Garden of the Hesperides, which are given to Hera and Zeus as a wedding gift by Gaia (Gaea). ${ }^{2}$ In this myth, apple is significant as it is a gift and it also symbolizes the beginning of man and woman's union because it is given as a wedding gift. It can be suggested that Gaia's wedding gift to Zeus and Hera seems to be the prototype of a custom in Greece, since, giving an apple or a pomegranate to brides in Greece is one of the most important practices during the wedding ceremony. For this reason, "in Greece, apples and even lemons were not disdained to show love" (Trumpf 1960: 16). Moreover, this custom is not restricted to the 
ancient times, but it also extends to the modern era, for in Greece "throwing an apple is [still] used as a sign to express love or to make a proposal of marriage" (Tozer 1869: 331; see also Nardo 2002: 23; Roman \& Roman 2010: 89). Here I would like to refer to Lesley Bolton's following sentences about this issue.

Gaia's wedding gift to Hera was a tree of golden apples. The tree was planted in the Garden of the Hesperides and protected by the nymphs. This first ceremony became the standard for sacred marriage throughout Greece. ... It became tradition in Athens for the brides to be given apples and pomegranates, which were favorites of Hera. (Bolton 2002: 75)

"The Judgment of Paris" is a more interesting and more famous myth concerned with the current topic. According to this myth, which is also known as the "apple discord", goddess Eris throws a golden apple among the gods during the wedding ceremony of Thetis and Peleus, with a note reading "for the fairest", since she is not invited to the wedding ceremony by the gods. Unsurprisingly, each of the goddesses claims that the note written on that golden apple is for them. Because of the discussion between the goddesses, someone must make a judgment on this issue. However, in any case, two of them would be angry, so Zeus does not want to wrangle with them and sends them to Paris for the judgment of this difficult case. Each of them promises various things to Paris to influence his judgment. Paris gives the apple to Aphrodite who promises him the love of the most beautiful woman of that time. This judgment launches a terrible problem, which causes the Trojan War, because the most beautiful woman of that time is Helen, the wife of the Spartan King Menelaus. So, the cause of the Trojan War, described by Homer in the Iliad, is Helen being kept and taken to Troy by Paris (Morford \& Lenardon 2003 [1971]: 483, 765).

In this tale, the motif of apple is involved in the events with a few different aspects. First of all, an apple is given to a woman as a token of her beauty. Secondly, the instigator of this judgment about beauty is also a woman, namely Helen; thus apple symbolizes both the beauty of a woman and love between woman and man. This myth is important because the main meanings of apple in this myth are, as can be seen in the examples below, valid in many other cultures and apple is not only a symbol of good wishes but also a token of love.

The role of apple in ancient Greece was not restricted only to these myths; on the contrary, there are myths like those of Atalanta and Acontius, in which the motif of apple is used in the same meaning. For example, according to the myth of Atalanta, she stipulates a footrace for the men who want to marry her, and she also declares that the ones who lose the race will be executed as a punishment. Plenty of men are executed according to the deal because they cannot win the race. But Milanion (or Hippomenes) wins the race and mar- 
ries Atalanta with the help of three golden apples which are given to him by Aphrodite. During the race, Milanion drops these golden apples one by one. As Atalanta stops to take a look at the apples, Milanion manages to win the footrace. Once again the motif of apple has a function symbolizing both the relations between man and woman and the wedding. Furthermore, it can be suggested that the golden apples in this myth are also wedding gifts. In this context, one of the sixth-century poets, Arabius Scholasticus, "considers that the apples which Hippomenes threw near Atalanta were not only a device whereby he could win the race, but also a wedding present" (Littlewood 1968: 156). One of the points that support this comment is that Greeks use the apple both as a gift and as a symbol of wedding. By the way, it can be suggested that there is a connection between apples and Aphrodite, since we encounter Aphrodite once again in regard to golden apples in this myth (Trumpf 1960: 18-19; see also Foster 1899: 42, 44-45).

Another distinctive example for the usage of apple in the same context is the myth of Acontius and Cydippe. According to this myth, Acontius loves Cydippe in spite of the difference between their social classes. Because of this, Acontius puts an apple on Cydippe's path with a note saying, "I swear to Artemis to marry none but Acontius". When Cydippe finds this apple, she reads the note aloud and this way she swears allegiance. When her parents try to make her marry a suitable man, she gets sick and cannot do it. Eventually, her accidental promise is revealed and Cydippe marries Acontius (Morford \& Lenardon 2003 [1971]: 616; see also Roman \& Roman 2010: 10). In this myth apple appears once again in connection with marriage, namely the relationship between man and woman. In addition to this, the note which is written on the apple reminds that this fruit can be used also for communication. "As elsewhere in Greece, throwing an apple to the lover expresses love and the desire for a union, even if sometimes that apple is an already bitten one" (Trumpf 1960: 16; see also Foster 1899: 50).

These properties of apple are not a specificity of the Greeks as the same usage of apple within similar contexts can be found also in other cultures. For example, in Irish mythology, Cathal mac Fionghuine, who is the king of Ulster, constantly sends apples to his beloved, Liogach, as a gift. In Norse mythology, the motif of apple appears as a symbol of a proposal and a gift as we can see in the tale of Gerda and Frey. In this tale Frey makes a proposal with apples and a ring in order to win his beloved goddess Gerda's heart (Coleman 2007: 197, 408). In a Polish legend, however, the hero rescues the princess from the castle where she is kept, by gathering golden apples just like in the tale of the Garden of the Hesperides (Folkard 1884: 223). We can find yet another example from Scotland: 
In Lowland Scotland, there is an old charm still practiced by village maidens on Halloween. It is to go alone into a room, and eat an Apple in front of a looking-glass, when the face of the future husband will appear looking over the maid's shoulder. (Folkard 1884: 220)

It is obvious that this belief is also related to marriage and the relationship between lovers.

The Germans also frequently use the motif of apple in their folktales. For example, in almost every folktale collected by the Brothers Grimm, we encounter the apple as an important motif. Especially in the tales "The White Snake" and "Iron Hans" the motif of apple is obviously used in order to indicate marriage. In "The White Snake" a young man brings a golden apple from the tree of life to the princess in order to marry her. In "Iron Hans" the son of a gardener deserves to marry the king's daughter by catching the golden apples which are thrown by the princess at random times on three days (Grimm \& Grimm 1909: 201, 324-325).

As far as we know, apple has similar functions also in the Balkans. For example, "in Serbia, when a maiden accepts from her lover an Apple [sic], she is engaged. In Hungary, a betrothed maiden, after having received from her lover the 'engaged' [sic] ring, presents him with an Apple [sic], the special symbol of all nuptial gifts" (Folkard 1884: 221). And "in Sicily, when a young man is in love, he presents the object of his affections with a love Apple [sic]" (ibid.: 222).

Many more examples of the motif of apple in the same context can be found in Eastern cultures as well. One of the most famous examples concerned with this issue is The Arabian Nights. Many stories in this anonymous book include the motif of apple. One of these stories is "Uns Al-Wujud and the Wazir's Daughter Alward Fi'l-Akmam or Rose-In-Hood", in which the daughter of the vizier not only attracts the attention of her favorite young man by throwing an apple towards him but also helps her sister recognize him among others (Book 1885: 33). We encounter the same theme in the "Story of the Three Princes and the Genius Morhagian and His Daughters"; namely, in this story the princess points out the hero whose name is Badialzaman by throwing an apple towards him (Book 1888: 367).

These aspects of apple are very conspicuous in the culture of Turks as well, since it is widely used in wedding ceremonies, and also as a tool for proposing and communication. "We know from various sources that Kirghiz women hit men with an apple and Uzbek women throw an apple at men to choose their prospective husbands; among Bashkir Turks, however, girls offer an apple to the chosen young men as bridegroom candidate" (Üstünova 2011: 150). Similar practices are ongoing in many regions of Anatolia even today. For example, "in Tunceli, the family of the bridegroom invite the people of surrounding villages 
to the wedding ceremony by sending them an apple which is named 'mum' (candle)" (Üstünova 2011: 150; see also Çoruhlu 2006: 11; Öztoprak 2006: 577). Here we can recall the evidence gathered by Işıl Altun during her field research.

Nubile girls in Artvin think that if they strip the peel off an apple without damaging it as a whole and put it under their pillows, they can see their future husband in their dreams. The people of Gürün in Sivas believe that seeing himself or herself while eating an apple in his or her dream is an indication of marriage for that person. (Altun 2008: 264)

It is possible to find many other examples in this context, as well as to elaborate on the examples above. However, it can be asserted that these examples alone should suffice to show that the motif of apple is really common in many cultures and it is in most cases used both to indicate the relationship between man and woman and to make the communication between lovers possible.

\section{ABRAHAMIC RELIGIONS AND THE MOTIF OF APPLE}

The motif of apple was on the agenda not only in ancient times, but it was also a common one in Abrahamic religions throughout the Middle Ages. Moreover, there are really important similarities between ancient cultures and Abrahamic religions in the usage of this motif. We even have strong evidence for suggesting that the deliberations in Abrahamic religions on this issue are the continuation of the ancient ones, as in the Abrahamic religions the apple symbolizes the relationship between man and woman just like in the ancient times. Apart from this fact, its other meanings have been forgotten while this meaning of apple is becoming more emphatic. So, to see the continuation of deliberations about the motif of apple we must also discuss the Abrahamic religions and their deliberations about this issue.

Although Abrahamic religions contain verses about the forbidden tree in the paradise and its fruit, neither the Bible nor the Quran speaks about apple. For example, in the Old Testament we can read about the tree and its fruit as follows:

The LORD God took the man and put him in the Garden of Eden to work it and take care of it. And the LORD God commanded the man, 'You are free to eat from any tree in the garden; but you must not eat from the tree of the knowledge of good and evil, for when you eat of it you will certainly die'. (Genesis 2/15-17)

But it is not clear which fruit it is. Although in Christianity the 'original sin' has an important place, there is no hint in the basic texts about the fruit that 
causes this original sin. There are verses about the forbidden tree in the Quran too, but again we cannot find anything about the fruit of this tree. In the following verse, it is mentioned only as a forbidden tree:

And we said: 'O Adam! Dwell you and your wife in the Paradise and eat both of you freely with pleasure and delight, of things therein as wherever you will, but come not near this tree or you both will be of the Zâlimûn (wrong-doers)'. (Al-Baqarah 2/35; see also Al-A'raf 7/19)

This means that the Bible and the Quran do not explain the fruit of the forbidden tree in plain and precise terms. It is not clear whether this explanation about the forbidden tree is metaphorical or not. Despite this obscurity, some opinions of this issue occur in oral traditions of these religions and the fruits like grape, fig, palm, and apple are considered as the fruit of the forbidden tree. Some commentators think that both the fruit and the tree are only metaphors for indicating sexual relations between Adam and Eve (see Folkard 1884: 217; Aça 2005: 15). One of the bases for this assertion is the verses that speak about their sexual organs, sexual relation being visible after having eaten the forbidden fruit and the emergence of the need to cover them (Genesis 3/1-8; see also Al-A'raf 7/20). ${ }^{3}$ Another opinion in the Islamic literature is related to the idea that the fruit of the forbidden tree makes eternality possible for the humankind, since one of the methods for being eternal is continuation of the progeny, which stipulates sexual relations. For this reason, Devil deceives Eve and then Adam by means of this argument, so we can think that the meaning of fruit is both sexual relations and children (Iqbal 1934 [1930]: 81-83).

We can leave aside these discussions because they constitute another aspect of this topic. According to this background it can be inferred that the most widely accepted fruit of the forbidden tree is apple, although there are different considerations about this issue. And there are a few different reasons for choosing apple as the fruit of the forbidden tree. Firstly, one can dwell on a linguistic viewpoint that the translation of "the tree of the knowledge of good and evil" from Hebrew to Latin changes the meaning of this expression to a certain extent, because "someone asserts that in the vulgate translation of the old testament from Hebrew to Latin 'the tree of the knowledge of good and evil' is translated as "malûm" (Aydar 2006: 104). In the Oxford Latin Dictionary the concept of 'mālum' is defined as “a term covering orig. most soft-skinned tree-fruit, but later normally specifying an apple. ... a fruit tree" (Glare 1968: 1069). However, the concept of 'malum', which is written a little differently from 'malûm', means "trouble, distress, pain, hardship, to make trouble for, harm ... a misfortune, Evil doing, harm, damage" (ibid.: 1068-1069). As a result, in the translation from Hebrew into Latin, the expression of "the tree of the knowledge of good 
and evil" is defined with the concept of 'malum', which means trouble, evil, distress or, owing to a little spelling difference, a tree, and fruit. "The person who reads and spreads this translation prefers the meaning of 'apple tree' for that concept. Thus, the consideration about the forbidden fruit that was eaten by Adam and Eve is widely accepted as being apple" (Aydar 2006: 104).

Another probable ground for considering the apple as the reason for the mankind having been expelled from the paradise is the traditions that originate in ancient times. For example, the golden apple trees in the Garden of the Hesperides remind us of the apple tree in the paradise, which is forbidden. In this respect, "this image, well-known in Roman times, may be the source of the tradition that the tree in the Garden of Eden was an apple" (Hall 1974: 150). Additionally, as it is mentioned above, apple implies a sexual relationship between women and men, so we can understand the reason why the apple is considered as a fruit that causes the fall of humankind from heaven, and why it is chosen over other fruits.

The motif of apple is used very rarely in the Christian art. For example, in general, Christ is described with an apple in his hand. This means the redemption of the sinful mankind with the help of Christ, because he is holding the apple which is the reason of the mankind's fall; namely, he picks it up (in this context both the apple and the mankind) from the place where it has fallen. As James Hall says, "the apple, usually held in the infant's hand, is traditionally the fruit of the Tree of Knowledge and therefore alludes to him as the future Redeemer of mankind from Original Sin" (Hall 1974: 330; see also Hall 1996: $129,142)$.

One may ask why, although the apple implies a sexual relationship between man and woman and it is also considered as the symbol of health due to its properties, it is considered to be the cause of the humankind's fall. How can this fruit simultaneously carry these contradictory meanings? It can be asserted that this is not a contradiction at all, since when we think about it for a while we can easily notice that all of these different meanings are part of the same system and they are a complement for the missing parts of the paradigm. Then, the healthy relationship between men and women is the basis for a happy life both in private and social contexts. If this relationship cannot be developed in a proper manner, it causes distress and collapse. Thus, those different meanings of the motif of apple which are implying the relationship between women and men cause both collapse (or fall from the paradise) and happiness; moreover, if we consider the meanings of this motif that are discussed above in this context, its different but related aspects will be clearer to us and we will be able to understand all the aspects in a proper way. 
The issue of the forbidden fruit and other related problems have crucial aspects in Abrahamic religions. However, it may be asserted that the issues emphasized above are both proper and sufficient for the purposes of this article. Thus, without discussing details anymore, I will now try to examine the usage of this motif in the folk songs of Anatolia, depending on this background.

\section{THE MOTIF OF APPLE IN ANATOLIAN FOLK SONGS}

The motif of apple is frequently used in Anatolian folk songs in the same way as in other cultures, since its meanings related to health, treatment, beauty, communication, proposal, and sexual relationship between men and women are completely similar to those in other cultures in Anatolia. The most prominent one of these properties is communication and proposal. This meaning of apple can be encountered almost everywhere from Central Asia to Anatolia, especially in the context of the ritual of throwing an apple. "Offering an apple to someone shows the desire of marriage or commitment in Asia and Anatolia" (Çoruhlu 2006: 11). This ritual can be applied mutually; namely, it means the proposal of a girl to a boy and vice versa. In both situations, it directly implies marriage or at least a relationship between men and women. For example, "the young Karakalpak girls and boys throw each other apples on Nawruz" (Üstünova 2011: 149). As we have already seen above, there are also similar rituals in Kirghiz, Uzbek, and Bashkir Turks.

The same practice has survived in Anatolia through some rituals. For example, "an Ottoman miniature from the 1600s, which is in the British Library now, can be demonstrated as evidence to this. In this miniature a young woman is pictured, holding an apple in her hand" (Çoruhlu 2006: 11-12). Moreover, we know that in some regions in Anatolia this ritual is performed even today. For example, "in some villages around Kars, a young man leaves an apple in front of his beloved's door and he understands whether or not she is interested in him through her decision about receiving or rejecting the apple; as we see, the apple is a 'communication tool' in this custom" (Gölpınarlı \& Boratav 1991: 53-54). Our resources that contain plenty of narratives show that this usage of the apple motif has been widespread in Turkish culture from the ancient times to the present day both in central Asia and in Anatolia (Akmataliyev 2001: 16; see also Ergun \& İbrahimov 1996: 75-81; Altun 2008: 268). If we consider the motif of apple in this context, most of the folk song texts that seem meaningless at first glance turn out to be meaningful. We can mention the following folk song from Elazığ, eastern Anatolia, titled Al Almayı Daldan Al ('Pick the red apple from the branch'), as an example collected by Neriman Tüfekçi from Vasfi Akyol. 
Al almayı daldan al Pick the red apple from the branch

Daldan alma benden al Don't pick it from the branch, rather take it from me

Duydum gelin olisin I heard that you will be bride

Dur ben ölüm ondan al Wait till I die, then take it [apple] from him

Al alma dört olaydı There would be four red apples

Yiyene dert olaydl

They would trouble whomever eats them

Bu almanin sahabı

The owner of this apple

Sözüne merd olaydı

Would abide by her promise

Al alma kızll alma

Red apple, ruby apple

Irafa dizil alma

Line up on the shelf

O yar bize gelende

When that beloved comes to us

Cebine süzül alma

(TRT 2006: 22)

Get into her pocket quietly

It is very clear that the motif of apple is used in this folk song as a tool for both communication and proposal. When the poet says, "take the apple from me, rather than a branch of tree" in the first two lines, he wishes that his proposal would be accepted by his lover. But the next verse reading, "the owner of this apple would abide by her promise", means that after she accepted the proposal, she went back on her promise. And with the last verse of the last quatrain he implies that he still hopes for her love and tries to send a message to her through the apple. In the following folk song, Pınarın Başında ('By the river'), collected by Ünsal Doğan, the motif of apple is used again as a medium of proposal.

Pınarın başına da bir güvercin A pigeon has landed by the river kondu

Sallanma sevdiğim aklım

Don't amble my darling, I've lost my

zay oldu mind

Çıkardı cebinden bir elma She gave me an apple out of her verdi pocket

Sandım yalan dünya hep benim I thought that the whole world oldu belongs to me. ${ }^{4}$

We encounter the motif of apple in other folk songs in the same way. For example, in a folk song from Diyarbakır, southeastern Turkey, collected by Muzaffer Sarısözen from Selahattin Mazlumoğlu, the verse lines "o kızın gönlü de seumiş / bana alma göndermiş" ("that girl has fallen in love with me / and she has sent an apple to me')" (TRT 2006: 209) are not only a sign of love, but also 
a forerunner to a proposal. This proposal can be made both by a man to a woman and by a woman to a man. The verse lines reading "elmayı top top yapalım / kızlara bahşiş atalım" ('let's roll the apple as a ball / and send it as a tip to the girls') (TRT 2006: 315), collected from Ziya Bulut by Muzaffer Sarısözen, mean that the apple is a gift for girls and it is also a proposal to girls by boys. Except for this, these verse lines make us recall the corresponding scene in the "tradition of throwing an apple", which is emphasized above.

In one of the Neşet Ertaş's folk songs titled Ayva Turunç Narım Var ('I have a quince, a sour orange, and a pomegranate') the motif of apple is used very strikingly. The usage of the apple and quince together in the verse lines "al almayı ver narı / ağlarım zarı zarı" ("take the apple then give the quince / otherwise I will bawl and cry') (TRT 2006: 92) is really significant, since in this context the apple refers to the proposal and the quince to the desired result, which comes after the acceptance of the proposal. Even if the apple has meanings like prosperity, fertility, health, beauty, and progeny (descendant, posterity), it stands out with the meanings of offer and communication. Although the quince has a usage similar to that of the apple, its meaning related to semination and progeny is more common in Anatolia than the other ones. Neşet Ertaş employs these motifs parallel to his cultural background by attributing the meanings of 'proposal' and 'progeny'.

In another folk song titled Elma Attım Nar Geldi ('I threw an apple then a quince came'), which was collected from Menküze Gedik by the staff members of Ankara State Conservatory, these motifs are used in the same manner as we can see in the verse lines "elma attım nar geldi / dar sokaktan yar geldi" ('I threw an apple then a quince came / my darling came along the narrow street') (TRT 2006: 312). Hereby I would like to quote Mustafa Duman's statements on this issue.

The usages of the pomegranate in the folk songs of Kirşehir make parallel references to the current beliefs. Although the pomegranate is used exactly in the same meaning as the apple in some contexts, it refers mostly to having a baby and continuation of genealogy, namely to semination. In this way, the pomegranate implies the next stage of the symbolic meaning of the apple. (Duman 2013: 802)

Ip Attım Ucu Kaldı ('I knotted a rope except its end') is also a folk song from Kirıkkale, central Anatolia, which refers to the proposal and the relation of woman and man through the motif of apple. One can easily notice that the text has a really dramatic structure. The song describes a woman who is weaving a carpet in front of a loom by giving the details of the story. The verse lines 
"almayı yüke koydun / ăgzını büke koydun" ('you put the apple into the jug bag / and twisted its open side') imply that she will never accept an apple, namely a proposal, from the man she loves. The following verses of this folk song even strengthen this meaning.

Ip attım ucu kaldı I knotted the rope except its end

Tarakta gücü kaldı The rope of the loom stayed on the reed

Ben sevdim eller aldr I loved but another one got his hand

Yürekte acı kaldı So, stayed only pain in heart

Almayı yüke koydun You put the apple into the jug bag

A $\breve{z}$ ını büke koydun And twisted its open side

Aldın yari elimden You stripped me of my darling

Boynumu büke koydun And made me sad

(Duman 2013: 799)

If and only if one knows the historical background of the apple motif, the text of the folk song will be meaningful; otherwise this text would be considered as nonsense, with the only aim to rhyme. But we can show some other examples, such as Al Alma Gönül Alma ('Red apple captures the heart'), where the motif of apple is used not implicitly, but, on the contrary, explicitly. The text of this Kars folk song, collected by Ali Ekber Çiçek from Kurbani Kılıç, is as follows.

Al alma gönül alma

Allanıp yenil alma

Seni yare yolladım

Kazandım gönül alma

Ağaçta sallanırsan

Sallanıp ballanırsan

Bazen emanet olup

O yare yollanirsan

(TRT 2006: 22)
Red apple captures the heart

It is eaten when it turns red

I sent you to my darling

I captured his/her heart

You swing on a tree and

Sweeten while you are swinging

Sometimes as a trust

You are sent to that darling

It is possible to give more examples of this topic both from anonymous texts and from troubadours; in addition to this, some examples can be found from contemporary poets who are using this motif in the same contexts (see, e.g., Şehriyâr 1990: 25; Uyar 2008 [2002]: 17). But it can be assumed that the examples discussed above will suffice for the purpose of this article. Below I will present some specifics about this topic, which depend on the information above. 


\section{CONCLUSION}

We encounter the motif of apple in a great deal of cultures and in every era. Although there are some nuances in the usage of this motif, its meaning and importance is, however, common in the cultures that are discussed in this article. In addition, this motif occupies an important position in the oral traditions of Abrahamic religions. As a result, it is not an overlooked motif in the history of culture; on the contrary, it is a common motif both in the history of art and in daily life. The main properties of this motif, which is practically common to all cultures, are its direct or indirect implication to the relationship between man and woman, and its usage as a tool of communication or proposal.

We can suggest that this motif is used in Anatolian folk songs in the same context as in the history of culture, since plenty of texts that are exemplified above show that there is serious parallelism in this topic between Anatolian folk songs and other cultural traditions, which comes through antiquity. There are two important aspects of knowing the historical background of these motifs. First of all, unless we study some common motifs of the history of culture, the meaning of these cultural texts will stay hidden to us as some of these folk songs are culturally coded and they must be decoded through a hermeneutical approach. As Gadamer (1994 [1975]: 303) asserts, "If we fail to transpose ourselves into the historical horizon from which the traditionary text speaks, we will misunderstand the significance of what it has to say to us". And we can suggest that one of the methods for transposing ourselves into the historical horizon is to learn both the meaning and historical background of cultural motifs.

As a result, one must learn some symbols and motifs to understand the cultural issues. If one tries to learn some of these motifs, plenty of folk songs open themselves to the reader (or to the listener). Moreover, when one understands the usage of some cultural motifs in different regions, he or she can expand his or her horizon about art and also see continuity in the history of culture. In addition to this, one of the methods to grasp the cultural transitivity is to notice these common issues and the continuity of cultural elements. If we consider the motif of apple in this context, we can understand both the meanings of Anatolian folk songs that contain this motif, and the place of Anatolian folk songs in the history of culture. Namely, as we have seen throughout this paper, Anatolian folk songs bear the traces of enclosing cultures. But the elements of these enclosing cultures are used in an original manner and new folk art works are synthesized. Because of this, to understand the Anatolian folk songs through a hermeneutical approach makes it possible to see the cultural continuity in the history of culture. 


\section{NOTES}

1 This article is a reviewed and extended version of my speech at the 5th European Conference on Social and Behavioral Sciences in St Petersburg, on September 11-14, 2014.

2 The concept of " $\mu \eta \lambda o v$ " ('melon') which means 'apple' in ancient Greek is not used only to express apple, since Liddell, Scott, and Jones define it as "apple or (generally) any tree fruit" (see Liddell \& Scott \& Jones 1996 [1843]: 1127). This means that the fruits that are called melon in ancient Greece are probably round fruits like apples, oranges, lemons, and pomegranates. But linguistic and etymological debates on this concept are not the main topic of this article, so they are not discussed in detail (see also McCartney 1925: 73).

3 The themes like "forbidden fruit", "to be expelled from the paradise", and "the relation between fruit and the other world" are also common in different cultures. For example, the concept of the otherworld in the Celtic culture is embodied by Avalon, namely Island of Apples (see Monaghan 2004: 28).

4 This folk song cannot be found in a printed book or article, because it has been collected nowadays by Ünsal Doğan. So, the text can be found in his album titled Erenler Yadigarl ('Saints' Memento', 2013).

\section{REFERENCES}

Aça, Mehmet 2005. Türk İnanış ve Düşünüş Sistemlerinde Meyve. [Fruit in Turkish Faith and Thinking Systems.] In: G. Gülsevin \& M. Arıkan (eds.) Prof. Dr. Fikret Türkmen Armă̆anı. [In Honour of Fikret Türkmen.] İzmir: Kanyılmaz matbaası, pp. 11-22.

Akmataliyev, Abdıldacan 2001. Kırgız Folkloru ve Tarihi Kahramanlar (Evlilik Geleneği ve Türküleri, Çocuk Folkloru, Edebi Eser ve Tarihi Kahramanlar). [Kırgız Folklore and Historical Heroes (Marriage Customs and Folk Songs, Children's Folklore, Literary Works and Historical Heroes).] Adapted by Kalmamat Kulamshaev. Ankara: Atatürk Kültür Merkezi.

Altun, Işıl 2008. Türk Halk Kültüründe Elma. [Apple in the Turkish Folk Culture.] Turkish Studies International Periodical for the Languages, Literature and History of Turkish or Turkic, Vol. 3/5, pp. 262-281.

Aydar, Hidayet 2006. Adem'in Meyvesi. [Adam's Fruit.] In: E. G. Naskali \& D. Herkmen (eds.) Meyve Kitabl. [Book of Fruit.] Istanbul: Kitabevi, pp. 83-104.

Bolton, Lesley 2002. The Everything Classical Mythology Book: Greek and Roman Gods, Goddesses, Heroes, and Monsters from Ares to Zeus. Avon, Mass.: Adams Media Corporation.

Book 1885 = The Book of the Thousand Nights and a Night, Vol. 5. Transl. by Richard Francis Burton. USA: The Burton Club. Available at http://www.burtoniana.org/ books/1885-Arabian\%20Nights/, last accessed on April 27, 2017. 
Book 1887 = Supplemental Nights to the Book of the Thousand Nights and a Night, Vol. 3. Transl. by Richard Francis Burton. USA: The Burton Club. Available at http://www.burtoniana.org/books/1885-Arabian\%20Nights/, last accessed on April 27, 2017.

Book 1888 = Supplemental Nights to the Book of the Thousand Nights and a Night, Vol. 6. Transl. by Richard Francis Burton. USA: The Burton Club. Available at http://www.burtoniana.org/books/1885-Arabian\%20Nights/, last accessed on April 27, 2017.

Coleman, James A. 2007. The Dictionary of Mythology: An A-Z of Themes, Legends and Heroes. London: Arcturus.

Çoruhlu, Yaşar 2006. Meyve Sunma Sahnelerinin Anlamı. [The Meaning of Fruit Presentation Scenes.] In: E. G. Naskali \& D. Herkmen (eds.) Meyve Kitabr. [Book of Fruit.] Istanbul: Kitabevi, pp. 3-19.

Duman, Mustafa 2013. Kırşehir Türkülerinde Meyve. [Fruit in Kırşehir Folk Songs.] IV. International Student Congress of Turkish Language and Literature 2012. Proceedings. İstanbul: İstanbul Kültür University Press, pp. 795-810.

Eberhard, Wolfram 1986. A Dictionary of Chinese Symbols: Hidden Symbols in Chinese Life and Thought. Transl. by G. L. Campbell. London \& New York: Routledge \& Kegan Paul.

Ergun, Metin \& İbrahimov, Gaynislam 1996. Başkurt Halk Destanı Ural Batır. [Bashkir Folk Epic Ural Batır.] Ankara: Gen.

Folkard, Richard 1884. Plant Lore, Legends and Lyrics. London: Sampson Low \& Marston \& Searle \& Rivington. Available at https://archive.org/details/ plantlorelegends00folk, last accessed on April 12, 2017.

Foster, Benjamin Oliver 1899. Notes on the Symbolism of the Apple in Classical Antiquity. Harvard Studies in Classical Philology, Vol. 10, pp. 39-55. Available at https:// archive.org/details/jstor-310298, last accessed on April 19, 2017.

Gadamer, Hans-Georg 1994 [1975]. Truth and Method. 2nd edition. Transl. by Joel Weinsheimer \& Donald Marshall. London \& New York: Continuum.

Glare, P. G. W. 1968. Oxford Latin Dictionary. London: Oxford University Press.

Gölpınarlı, Abdülbaki \& Boratav, Pertev Naili 1991. Pir Sultan Abdal. İstanbul: Der.

Grimm, Wilhelm \& Grimm, Jacob 1909. The Fairy Tales of the Brothers Grimm. Transl. by Edgar Lucas. New York: Doubleday.

Hall, James 1974. Dictionary of Subjects and Symbols in Art. New York: Harper \& Row.

Hall, James 1996. Illustrated Dictionary of Symbols in Eastern and Western Art. Boulder, CO: Westview Press.

Hentsch, Thierry 2008. Hayali Doğu: Batı'nın Akdenizli Doğu'ya Bakışı. [Imagining the Middle East.] Transl. by Aysel Bora. İstanbul: Metis.

Genesis = Holy Bible: Today's New International Version. 2005. Colorado Springs, CO: International Bible Society.

Iqbal, Mohammad 1934 [1930]. The Reconstruction of Religious Thought in Islam. London: Oxford University Press.

Jordan, Michael 2004 [1993]. Dictionary of Gods and Goddesses. New York: Facts on File. Available at https://www.pdf-archive.com/2016/10/07/dictionary-of-gods-andgoddesses/, last accessed on April 20, 2017. 
Keskin, Yahya Mustafa 2001. Kırsal Kesimde Yaşayan Alevilerde Doğum Geleneğine İlişkin İnanç ve Uygulamalar. [The Beliefs and Practices about Birth Customs in Alevi People Who Live in the Countryside.] Furat Üniversitesi Illahiyat Fakültesi Dergisi, Vol. 6, No. 1, pp. 41-54.

Liddell, Henry George \& Scott, Robert \& Jones, Henry Stuart 1996 [1843]. A GreekEnglish Lexicon. Oxford: Clarendon Press.

Littlewood, A. R. 1968. The Symbolism of the Apple in Greece and Roman Literature. Harvard Studies in Classical Philology, Vol. 72, pp. 147-181. DOI: 10.2307/311078.

Macbain, Alexander 1885. Celtic Mythology and Religion. Inverness: A. \& W. Mackenzie. Available at https://archive.org/details/celticmythologya00macbuoft, last accessed on April 20, 2017.

McCartney, Eugene Stock 1925. How the Apple Became the Token of Love. Transactions and Proceedings of the American Philological Association, Vol. 56, pp. 70-81. Available at https://archive.org/details/GardenFolkloreApple, last accessed on April 20, 2017.

Monaghan, Patricia 2004. The Encyclopedia of Celtic Mythology and Folklore. New York: Facts on File.

Morford, Mark P. O. \& Lenardon, Robert J. 2003 [1971]. Classical Mythology. New York: Oxford University Press.

Nardo, Don 2002. Greek and Roman Mythology. San Diego, CA: Greenhaven Press.

Öztoprak, Nihat 2006. Meyve İle İlgili Adetler. [Customs Related to Fruit.] In: E. G. Naskali \& D. Herkmen (eds.) Meyve Kitabı. [Book of Fruit.] İstanbul: Kitabevi, pp. 563-578.

Radloff, Wilhelm 1995. Manas Destanı. [Epic of Manas.] Edited by E. G. Naskali. Ankara: Türksoy.

Roman, Luke \& Roman, Monica 2010. Encyclopedia of Greece and Roman Mythology. New York: Facts On File.

Roux, Jean-Paul 2002. Türklerin ve Moğolların Eski Dini. [Old Religion of Turks and Mongols.] Transl. by Aykut Kazancigil. İstanbul: Kabalcı. Available at https:// docs.google.com/file/d/0B1DTbZaefcBrelljW19jZkxuajA/edit, last accessed on April 20, 2017.

Şehriyâr, Muhammed Hüseyin 1990. Haydar Baba'ya Selam. [Greetings to Haydar Baba.] Edited by Selahattin Kılıç \& İlhan Şimşek. Ankara: Kültür Bakanlığı.

Sever, Mustafa 2004. Türk Halk İnançlarında ve Halk Hekimliği Uygulamalarında Meyve. [Fruit in Turkish Folk Beliefs and Traditional Folk Medicine.] Journal of Turkology Research, Vol. 16, pp. 95-109. Available at http://tubar.com.tr/ TUBAR\%20DOSYA/pdf/2004GUZ/6.\%20mustafa\%20sever.pdf, last accessed on April 20, 2017.

The Noble Qur'an 1419. Transl. by Muhammed Taqî-ud-Dîn Al Hilâlî \& Muhammad Muhsin Khân. Madinah: King Fahd Complex. Available at https://ia800209.us.archive.org/22/ items/EnglishTranslationOfTheNobleQuranByTaqiUdDinAlHilaliAndMuhsinKhan/ The_Holy_Quran_English.pdf, last accessed on April 27, 2017.

Tozer, Henry Fanshawe 1869. Researches in the Highlands of Turkey. Vol. 2. London: John Murray. Available at https://archive.org/details/researchesinhigh02tozeuoft, last accessed on April 20, 2017. 
Tozlu, Necdet 2011. Kerem ile Aslı Hikâyesinin İki Eş Metninin Karşılaştırılması. [Comparison of Two Peer Texts of the Tale of Kerem and Aslı.] E-Journal of New World Sciences Academy, Vol. 6, No. 2, pp. 356-372.

TRT 2006 = Türk Halk Müziği Sözlü Eserler Antolojisi. Vol. 1. [Anthology of Turkish Folk Songs.] Ankara: TRT.

Trumpf, Jürgen 1960. Kydonische Äpfel. [Cydonian Apple.] Hermes, Vol. 88, No. 1, pp. 14-22.

Üstünova, Kerime 2011. Erzurum Düğünleri'nde 'Elma Atma' Geleneği. [Apple Throwing Tradition in the Weddings of Erzurum.] Millî Folklor, Vol. 90, pp. 146-155. Available at http://www.millifolklor.com/Yayin/90, last accessed on April 20, 2017. Uyar, Turgut 2008 [2002]. Büyük Saat. [Big Clock.] İstanbul: YKY.

Ahmet Emre Dağtaşoğlu works as Assistant Professor at the University of Trakya, Turkey.

edagtasoglu@gmail.com 